\title{
cdc25 $5^{+}$Encodes a Protein Phosphatase that Dephosphorylates p34 ${ }^{\text {cdc2 }}$
}

\section{Margaret S. Lee, ${ }^{*}$ Scott Ogg, ${ }^{*}$ Min $\mathrm{Xu},{ }^{*}$ Laura L. Parker, ${ }^{*}$ Daniel J. Donoghue, $†$ James L. Maller, $\neq$ and Helen Piwnica-Worms*}

\begin{abstract}
*Department of Physiology, Tufts University School of Medicine, Boston, Massachusetts 02111; †Department of Chemistry and Center for Molecular Genetics, University of California, San Diego, LaJolla, California 92093-0322; and †Howard Hughes Medical Institute and Department of Pharmacology, University of Colorado School of Medicine, Denver, Colorado 80262
\end{abstract}

Submitted to Cell Regulation August 15, 1991; Accepted September 17, 1991

To determine how the human cdc25 gene product acts to regulate $\mathrm{p} 34^{\mathrm{cdc} 2}$ at the $\mathrm{G} 2$ to $\mathrm{M}$ transition, we have overproduced the full-length protein (cdc25Hs) as well as several deletion mutants in bacteria as glutathione-S-transferase fusion proteins. The wild-type cdc $25 \mathrm{Hs}$ gene product was synthesized as an $80-\mathrm{kDa}$ fusion protein $\left(\mathrm{p} 80^{\mathrm{GST}-\mathrm{cdc} 25}\right.$ ) and was judged to be functional by several criteria: recombinant $\mathrm{p} 80^{\mathrm{CST}-\mathrm{cdc} 25}$ induced meiotic maturation of Xenopus oocytes in the presence of cycloheximide; $\mathrm{p} 80^{\mathrm{GST}}$-cdc25 activated histone $\mathrm{H} 1$ kinase activity upon addition to extracts prepared from Xenopus oocytes; $\mathrm{p} 80^{\mathrm{GST}-\mathrm{cdc} 25}$ activated p34 ${ }^{\text {cdc2 }}$ /cyclin B complexes (prematuration promoting factor) in immune complex kinase assays performed in vitro; $\mathrm{p} 80^{\mathrm{GST}-\mathrm{cdc} 25}$ stimulated the tyrosine dephosphorylation of $\mathrm{p} 34^{\text {cdc2 }} /$ cyclin complexes isolated from Xenopus oocyte extracts as well as from overproducing insect cells; and $\mathrm{p} 80^{\mathrm{GST}-\mathrm{cdc} 25}$ hydrolyzed $p$-nitrophenylphosphate. In addition, deletion analysis defined a functional domain residing within the carboxy-terminus of the cdc $25 \mathrm{Hs}$ protein. Taken together, these results suggest that the cdc $25 \mathrm{Hs}$ protein is itself a phosphatase and that it may function directly in the tyrosine dephosphorylation and activation of $\mathrm{p} 34^{\mathrm{cdc} 2}$ at the $\mathrm{G} 2$ to $\mathrm{M}$ transition.

\section{INTRODUCTION}

The induction of DNA synthesis (S phase) and mitosis (M phase) in eukaryotic cells requires a serine/threonine protein kinase, known as p34 cdc2 (Reed, 1980; Nurse and Bissett, 1981; Simanis and Nurse, 1986; Blow and Nurse, 1990; Furukawa et al., 1990). p34 ${ }^{\text {cdc2 }}$ is the human homolog of the cdc2 gene product in the fission yeast, Schizosaccharomyces pombe, and of the CDC28 gene product in the budding yeast, Saccharomyces cerevisiae (Beach et al., 1982; Lee and Nurse, 1987). p34 ${ }^{\text {cdc2 }}$ is ubiquitous in eukaryotes (for review see Nurse, 1990). Although the amount of $\mathrm{p} 34^{\text {cdc2 }}$ remains constant throughout the cell cycle, its activity oscillates dramatically (Draetta and Beach, 1988; Labbe et al., 1988; Booher et al., 1989; Gautier et al., 1989; Moreno et al., 1989). The regulation of $\mathrm{p} 34^{\mathrm{cdc} 2}$ involves changes in both its state of phosphorylation and its association with other cell cycle regulatory proteins.

In $S$. pombe, two proteins, $13^{\text {suci }}$, the product of the suc1 ${ }^{+}$gene (Brizuela et al., 1987) and $\mathrm{p} 56^{\mathrm{cdc13}}$, the prod- uct of the $\mathrm{cdc} 13^{+}$gene (Moreno et al., 1989), physically associate with $\mathrm{p} 34^{\mathrm{cdc2}}$. Data from $S$. pombe suggest that $\mathrm{p} 13^{\text {suc1 }}$ may be involved in inactivating $\mathrm{p} 34^{\mathrm{cdc2}}$ and facilitating exit from mitosis (Moreno et al., 1989). In Xenopus, however, $\mathrm{p} 13^{\text {suc1 }}$ has been shown to inhibit activation and tyrosine dephosphorylation of $\mathrm{p} 34^{\mathrm{cdc} 2}$ (Dunphy and Newport, 1989). p56 $6^{\mathrm{cdc} 13}$ is a B-type cyclin. Cyclins fall into two classes on the basis of sequence differences as well as differences in the timing of their accumulation and degradation throughout the cell cycle (Swenson et al., 1986; Pines and Hunter, 1989, 1990; Westendorf et al., 1989; Minshull et al., 1990). It is a Btype cyclin that along with $\mathrm{p} 34^{\mathrm{cdc} 2}$ comprises maturation promoting factor (MPF) (Dunphy et al., 1988; Gautier et al., 1988, 1990; Lohka et al., 1988; Draetta et al., 1989). Association with the cyclins is necessary for the activation of $\mathrm{p} 34^{\mathrm{cdc} 2}$ kinase activity and for the entry of cells into mitosis (Minshull et al., 1989; Murray and Kirschner, 1989). Likewise, proteolytic degradation of cyclin is required for inactivation of $\mathrm{p} 34^{\text {cdc2 }}$ kinase ac- 
tivity and exit of cells from mitosis (Murray et al., 1989; Roy et al., 1991).

The following model for the regulation of $\mathrm{p} 34^{\mathrm{cdc} 2}$ has emerged through the work of several laboratories over the past few years. Early in the cell cycle (G1), p34 ${ }^{\text {cdc2 }}$ exists in monomeric form and serine phosphorylation is detected (Draetta and Beach, 1988; Krek and Nigg, 1991). As cells progress from the $G 1$ to the $G 2 / M$ phases of the cell cycle, cyclins accumulate and bind to p34 ${ }^{\mathrm{cdc} 2}$ (Draetta et al., 1989; Minshull et al., 1990). Cyclin binding facilitates the phosphorylation of $\mathrm{p} 34^{\mathrm{cdc} 2}$ (Solomon et al., 1990; Meijer et al., 1991; Parker et al., 1991). Both tyrosine (Tyr 15) and threonine (Thr 14 and presumably Thr 161) residues are phosphorylated (Draetta et al., 1988; Gould and Nurse, 1989; Lewin, 1990; Krek and Nigg, 1991). Just before entry into mitosis, $\mathrm{p} 34^{\mathrm{cdc2}}$ is dephosphorylated on Thr 14 and Tyr 15 and its kinase activity is activated (Dunphy and Newport, 1989; Gautier et al., 1989; Gould and Nurse, 1989, 1990; Morla et al., 1989; Krek and Nigg, 1991). In fission yeast, the substitution of phenylalanine for tyrosine (at position 15) advances cells prematurely into mitosis, indicating that the dephosphorylation of tyrosine 15 is a key step in the activation of p34 ${ }^{\text {cdc2 }}$ function (Gould and Nurse, 1989).

Although the kinases and phosphatases that are responsible for the cell cycle-dependent phosphorylations/dephosphorylations of $\mathrm{p} 34^{\text {cdc2 }}$ have not yet been identified, two mitotic control genes have been identified in S. pombe that are thought to regulate $\mathrm{p} 34^{\mathrm{cdc} 2}$ function by altering its state of phosphorylation. These genes include cdc $25^{+}$and wee $1^{+}$(Russell and Nurse, 1986, 1987). Genetic evidence suggests that $\operatorname{cdc} 25^{+}$encodes an activator of $\mathrm{p} 34^{\text {cdc2 }}$, whereas wee $1^{+}$encodes a negative regulator. The products of both the wee $1^{+}$and the cdc $25^{+}$genes act antagonistically to regulate $\mathrm{p} 34^{\text {cdc2 }}$ and thereby precisely control the timing of entry into mitosis (Russell and Nurse, 1987).

To decipher the temporal and molecular regulation of $\mathrm{p} 34^{\mathrm{cdc2}}$ as well as to identify the kinases and phosphatases that modify $\mathrm{p} 34^{\mathrm{cdc} 2}$ throughout the cell cycle, we overproduced p34 $4^{\text {cdc2 }}$ as well as several of its regulators using a baculoviral expression system (Parker $e t$ al., 1991). We made the surprising observation that p3 $4^{\text {cdc2 }}$ becomes phosphorylated on tyrosine 15 when coproduced with p107weel in insect cells, suggesting a role for $\mathrm{p} 107^{\text {weel }}$ in the regulation of $\mathrm{p} 34^{\text {cdc2 }}$ by tyrosine phosphorylation. In support of this, genetic data in fission yeast have demonstrated that wee $^{+}$acts redundantly with mik $1^{+}$in regulating the tyrosine phosphorylation of $\mathrm{p} 34^{\mathrm{cdc2}}$ (Lundgren et al., 1991).

If wee $^{+}$is involved in regulating the tyrosine phosphorylation of $\mathrm{p} 34^{\mathrm{cdc} 2}$ and if cdc25 $5^{+}$acts in opposition to $\mathrm{p} 107^{\mathrm{wee}}$, then one might predict that cdc25 $5^{+}$is involved in the tyrosine-dephosphorylation of $\mathrm{p} 34^{\mathrm{cdc} 2}$. Several lines of evidence are supportive of this model: 1 ) in yeast mutants containing a temperature-sensitive allele of $\operatorname{cdc} 25^{+}$, the tyrosine phosphorylated/inactive form of $\mathrm{p} 34^{\mathrm{cdc} 2}$ accumulates at the nonpermissive temperature. Upon shift to the permissive temperature, p34 ${ }^{\text {cdc2 }}$ becomes dephosphorylated on tyrosine coincident with its activation (Gould and Nurse, 1989); 2) the phosphotyrosine-specific protein phosphatase from human T cells is able to functionally complement cdc $25^{+}$ in fission yeast (Gould et al., 1990); 3) bacterially produced string protein (Drosophila homolog of cdc25 $5^{+}$) dephosphorylates and activates Xenopus $\mathrm{p} 34^{\mathrm{cdc} 2}$ in whole cell extracts as well as in $\mathrm{p} 13^{\text {suc1 }}$ precipitates $(\mathrm{Ku}$ magai and Dunphy, 1991); and 4) bacterially produced human cdc25 protein dephosphorylates and activates p34 ${ }^{\text {cdc2 }}$ purified from starfish oocytes (Strausfeld et al., 1991). In each of these assay systems it can not be rigorously excluded that the cdc 25 protein actually regulates the activity of a phosphatase rather than possessing intrinsic protein phosphatase activity.

To characterize the biochemical activity associated with the $\mathrm{cdc}^{+} 5^{+}$protein and to elucidate the contribution made by $\mathrm{cdc} 25^{+}$to the regulation of $\mathrm{p} 34^{\mathrm{cdc} 2}$, we have overproduced full length as well as deletion mutants of the cdc 25 protein (human homolog) in bacteria. Recombinant cdc $25 \mathrm{Hs}$ protein was assayed functionally by microinjection into Xenopus oocytes as well as in vitro in extracts prepared from Xenopus oocytes. cdc $25 \mathrm{Hs}$ protein induced meiotic maturation of Xenopus oocytes in the presence of cycloheximide. In addition, cdc $25 \mathrm{Hs}$ protein induced the activation of $\mathrm{p} 34^{\mathrm{cdc} 2}$ in vitro on incubation in extracts prepared from Xenopus oocytes. Sodium vanadate (an inhibitor of phosphotyrosine-specific protein phosphatases) ablated the effects of recombinant cdc $25 \mathrm{Hs}$ protein. Incubation of precipitates of $\mathrm{p} 34^{\text {cdc2 }} /$ cyclin complexes (from Xenopus extracts or from insect cells infected with recombinant baculoviruses) with recombinant cdc $25 \mathrm{Hs}$ protein induced the tyrosine dephosphorylation of $\mathrm{p} 34^{\mathrm{cdc} 2}$ in vitro. Furthermore, cdc25Hs protein hydrolyzed $p$-nitrophenylphosphate (PNPP), a commonly used substrate for assaying tyrosine-specific protein phosphatase activity. Finally, mutational analysis indicated that residues 258-435, located within the $C$ terminus of the cdc 25 protein, were critical for cdc25Hs function in these assays.

\section{MATERIALS AND METHODS}

\section{Bacterial Expression}

pBSK1 (Sadhu et al., 1990) was digested with BamH1 and Xho I. The $2-\mathrm{kb}$ insert encoding the human homolog (cdc25Hs) of the $S$. pombe cdc $25^{+}$gene was isolated and ligated into the BamH1/Xho 1 site of pGC52 to generate pGC52(cdc25Hs). pGC52(cdc25Hs) was incompletely digested with Acc1 and then ligated to two partially overlapping oligonucleotides 5' CTGGATCCATGT $3^{\prime}$ and $5^{\prime}$ AGACATGGATCC $3^{\prime}$ to generate pGC52(cdc25Hs)-2. This step places a BamH1 site upstream of the initiation codon of cdc25Hs. pGC52(cdc25Hs)-2 was digested with $B a m \mathrm{H} 1$ and the 1.9-kb insert containing $\mathrm{cdc} 25 \mathrm{Hs}$ was isolated and ligated into the BamH1 site of pGEX-2T (Pharmacia, Piscataway, NJ) to generate pML25. JM109 cells were transformed with PGEX-2T or pML25 and protein expression was induced with 
$0.5 \mathrm{mM}$ isopropyl $\beta$-D-thiogalactopyranoside. One-liter cultures were routinely induced at an $\mathrm{OD}_{595}$ of $0.4-0.8$ for $3 \mathrm{~h}$ at $37^{\circ} \mathrm{C}$ and pelleted at $3800 \times \&$ for $15 \mathrm{~min}$. The pellet was resuspended in $50 \mathrm{ml}$ of phosphate-buffered saline (PBS) and the suspension was repelleted at $3200 \times \mathrm{g}$ for $15 \mathrm{~min}$. Bacterial pellets were stored at $-80^{\circ} \mathrm{C}$.

\section{Mutants}

Mutant constructs were created from pML25 as follows. N459: pML25 was partially digested with Pvu II and the 6.8-kb linear form was isolated and digested to completion with Sma I. The 6.3-kb fragment containing the majority of the $5^{\prime}$ cdc $25 \mathrm{Hs}$ coding sequence was isolated and recircularized by blunt-end ligation to create the plasmid pML25N459. This construct removes the coding region for the C-terminal 14 amino acids of cdc25Hs and replaces them with four unrelated amino acids. N435: pML25 was partially digested with Pst I and the linear form was isolated and cut to completion with Nsi I. The 6.2$\mathrm{kb}$ product was isolated and recircularized creating the plasmid pML25-N435, which codes for the cdc25 protein with the C-terminal 38 amino acids deleted and replaced with 11 unrelated amino acids. N300: pML25 was digested to completion with Bgl II and Sma I, and the 5.9-kb backbone was isolated and a forced ligation was set up to recircularize the plasmid. The resulting plasmid pML25-N300 codes for the $\mathrm{N}$-terminal 300 amino acids of cdc 25 protein with an additional 4-7 unrelated amino acids at the C terminus. N258: pML25 was digested to completion with Dra I and the 926-bp fragment was isolated and digested with Bam HI. The resulting 787-bp fragment was ligated as a BamH1/Sma I fragment into PGEX-2T to generate pML25-N258, which codes for the $\mathrm{N}$-terminal 258 amino acids of cdc 25 protein with an additional five unrelated amino acids at the $C$ terminus. C215: pML25 was digested to completion with Dra I and the 1062-bp Dra I-Dra I fragment containing the coding region for the C-terminal 215 amino acids of the cdc $25^{+}$protein was isolated and ligated into Sma I-linearized pGEX-2T to create pML25-C215. C173: pML25 was digested to completion with $\mathrm{Bgl}$ II and Sma I and the 964-bp fragment was isolated and ligated into Bam H1/Sma I-linearized pGEX-1 to create pML25-C173. This plasmid codes for the C-terminal 173 amino acids of $c \mathrm{cdc}^{+} 5^{+}$protein. Plasmids containing mutant constructs were transformed into JM109 cells and induced as described for the wild-type cdc25 protein. The predicted molecular weights for the mutant fusion proteins are as follows: $\mathrm{N} 459,79 \mathrm{kDa} ; \mathrm{N} 435,77 \mathrm{kDa}$; $300,61 \mathrm{kDa}$; $\mathrm{N} 258,57 \mathrm{kDa}$; $\mathrm{C} 215,51 \mathrm{kDa}$; and $\mathrm{C173}, 47 \mathrm{kDa}$.

\section{Protease Inhibitors}

Protease inhibitors were added to lysis, wash and reaction buffers as indicated in the text at the following concentrations: phenylmethylsulfonyl fluoride (PMSF) $2 \mathrm{mM}$, aprotinin (AP) $0.15 \mathrm{U} / \mathrm{ml}$, leupeptin (LP) $20 \mu \mathrm{M}$, pepstatin (PP) $20 \mu \mathrm{M}$.

\section{Preparation of Glutathione Beads}

Glutathione agarose beads (Sigma Chemical, St. Louis, MO) were hydrated in PBS and then washed once in NETN $(20 \mathrm{mM}$ tris[hydroxymethyl]aminomethane [Tris] $\mathrm{pH} 8.0,100 \mathrm{mM} \mathrm{NaCl}, 1$ mM EDTA, 0.5\% vol/vol NP40, PMSF, AP, and LP), once in NETN containing $0.5 \%$ bovine serum albumin (BSA) (wt/vol), followed by three washes in NETN (Kaelin et al., 1991).

\section{Purification of Glutathione S-transferase (GST) Fusion Proteins}

Method 1 (Column Chromatography). Frozen bacterial pellets from 1-l cultures were resuspended in $80-100 \mathrm{ml}$ of lysis buffer (either PBS with $1 \%$ vol/vol Triton X-100 and PMSF, AP, LP, PP for microinjection experiments or NETN for all other experiments) and lysozyme was added to $0.5 \mathrm{mg} / \mathrm{ml}$. After incubation on ice for $30 \mathrm{~min}$, pellets were sonicated three times for $10 \mathrm{~s}$ each with a probe tip sonicator (model 185, Branson Sonic Power Co., Danbury, CT) at the microtip limit. Lysates were clarified by centrifugation at $27000 \times g$ for $1 \mathrm{~h}$ at $4^{\circ} \mathrm{C}$, transferred to a fresh tube and re-centrifuged at $27000 \times g$ for $15 \mathrm{~min}$ at $4^{\circ} \mathrm{C}$. Clarified supernatants were recycled over a $1-\mathrm{ml}$ column of glutathione agarose for $16 \mathrm{~h}$ at $4^{\circ} \mathrm{C}$. Columns were washed extensively with lysis buffer and then elution buffer (either $20 \mathrm{mM}$ Tris, pH 8.0, $1 \mathrm{mM}$ dithiothreitol [DTT] with PMSF, AP, LP, and PP for microinjection experiments or phosphatase buffer $[25 \mathrm{mM}$ imidazole, pH 7.2, $1 \mathrm{mM}$ EDTA, 0.1\% vol/vol 2-mercaptoethanol with PMSF, AP, LP, and PP]). Bound proteins were then eluted with elution buffer containing $10 \mathrm{mM}$ reduced glutathione.

Method 2. GST fusion proteins were purified essentially as described (Kaelin et al., 1991). Frozen bacterial pellets from 50-ml cultures of induced JM109 cells were suspended in $5 \mathrm{ml} \mathrm{NETN}$. Cell suspensions were then sonicated three times for $5 \mathrm{~s}$ each, using a probe tip sonicator at its maximum setting. Sonicates were spun at $12000 \times g$ for $7 \mathrm{~min}$. Cleared supernatants were added to glutathione beads and were incubated at $4^{\circ} \mathrm{C}$ for $30 \mathrm{~min}(1-5 \mathrm{ml}$ of supernatant per $25 \mu \mathrm{l}$ of packed beads). Beads were washed five times with NETN and boiled in sodium dodecyl sulfate (SDS) sample buffer. Bound proteins were resolved by SDS-polyacrylamide gel electrophoresis (PAGE) and visualized by staining with Coomassie blue. For functional assays, the beads were washed four times with phosphatase buffer and were used directly or the recombinant proteins were eluted from the beads in phosphatase buffer containing $10 \mathrm{mM}$ glutathione.

\section{Xenopus Oocytes}

Frogs were primed with $50 \mathrm{IU}$ pregnant mares' serum gonadotropin in $0.1 \mathrm{ml} 36 \mathrm{~h}$ before surgical removal of ovaries. Stage $V 1$ oocytes were manually dissected from ovarian tissue and maintained in modified OR-2 medium ( $25 \mathrm{mM} \mathrm{N}$-2-hydroxyethylpiperazine- $N^{\prime}$-2-ethanesulfonic acid [HEPES] pH 7.4, $73 \mathrm{mM} \mathrm{NaCl}, 1 \mathrm{mM} \mathrm{MgCl}, 0.5$ $\mathrm{mM} \mathrm{CaCl}, 1 \mathrm{mM} \mathrm{KCl}, 50 \mu \mathrm{g} / \mathrm{ml}$ gentamycin [GIBCO, Grand Island, $\mathrm{NY}], 10 \mathrm{mM} \mathrm{NaHCO}{ }_{3}$, and $100 \mu \mathrm{g} / \mathrm{ml} \mathrm{BSA}$ ) at $18^{\circ} \mathrm{C}$.

\section{Meiotic Maturation}

Defolliculated oocytes were stimulated to mature with $10 \mu \mathrm{g} / \mathrm{ml}$ progesterone in modified OR-2 medium. For microinjection experiments, $50-100 \mathrm{nl}$ of sample containing bacterially produced recombinant protein (purified by column chromatography) in $20 \mathrm{mM}$ Tris, $\mathrm{pH} 8.0$, $1 \mathrm{mM}$ DTT, and $10 \mathrm{mM}$ glutathione was injected into oocytes. cdc25 fusion protein ( $\mathrm{p} 80^{\mathrm{GST}-\mathrm{dc} c 25}$ ) and GST were injected at varying concentration (20-400 $\mathrm{nM}$ final concentration). Injected oocytes were incubated at $18^{\circ} \mathrm{C}$ for the duration of the experiment. When cycloheximide was used, oocytes were incubated in medium supplemented with $0.5 \mu \mathrm{g} / \mathrm{ml}$ cycloheximide for $30 \mathrm{~min}$ before microinjection and were maintained in this concentration of drug for the entire experiment. Germinal vesicle breakdown (GVBD) was scored by white spot formation and was confirmed by fixation of the oocytes in $10 \%$ trichloroacetic acid followed by manual dissection of the oocytes.

\section{Extract Preparation}

Dilute Prophase Extracts. Stage VI oocytes were homogenized in modified MPF extraction buffer $(80 \mathrm{mM}$ beta glycerol phosphate, 50 $\mathrm{mM} \mathrm{NaF}, 20 \mathrm{mM}$ Na ethylene glycol-bis[ $\beta$-amino ethyl ether]$N, N, N^{\prime}, N^{\prime}$-tetraacetic acid [EGTA], $15 \mathrm{mM} \mathrm{MgCl}_{2}, 20 \mathrm{mM}$ HEPES, pH 7.5, 1 mM DTT, PMSF, LP, AP, and PP at a concentration of 10 $\mu \mathrm{l}$ of buffer per oocyte). In some instances vanadate was added to 1 $\mathrm{mM}$. The cytoplasmic protein fraction was prepared by centrifuging the lysate at $100000 \times g$ for $1 \mathrm{~h}$ at $4^{\circ} \mathrm{C}$. The supernatant was removed and stored at $-80^{\circ} \mathrm{C}$.

Concentrated Prophase Extracts. Extracts were prepared as described above except that oocytes were homogenized at a concentration of 1 $\mu l$ of MPF extraction buffer per oocyte. 


\section{A}
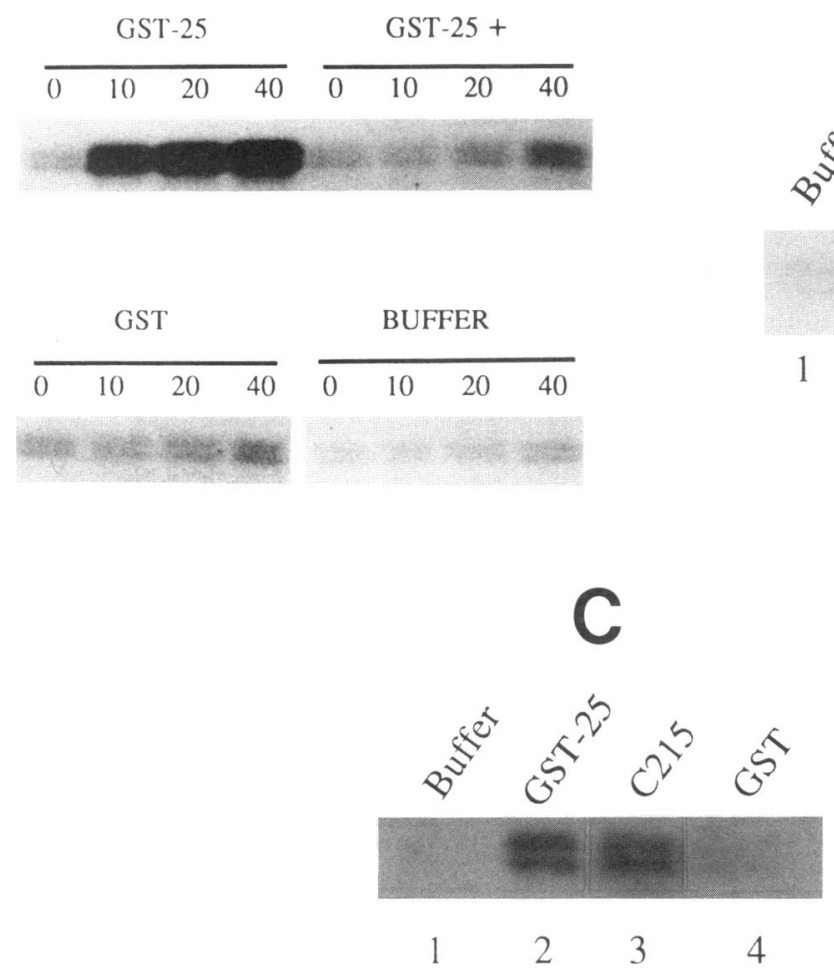

\section{Activation of MPF in Extracts Prepared from Stage VI Oocytes}

Reaction mixes were prepared in a final volume of $30 \mu \mathrm{l}$ containing $15 \mu$ l of dilute prophase extract and a final concentration of $40 \mathrm{mM}$ beta glycerol phosphate, $25 \mathrm{mM} \mathrm{NaF}, 7.5 \mathrm{mM} \mathrm{MgCl} 2,10 \mathrm{mM}$ HEPES, pH 7.5, $0.5 \mathrm{mM}$ DTT, $10 \mathrm{mM}$ NaEGTA, $10 \mathrm{mM}$ imidizole, pH 7.2, $0.4 \mathrm{mM}$ NaEDTA, $0.04 \% \mathrm{vol} / \mathrm{vol}$ B-mercaptoethanol, $10 \mathrm{mM}$ creatine phosphate, $1 \mathrm{mM}$ ATP, $0.04 \mathrm{mg} / \mathrm{ml} \mathrm{p80} 0^{\mathrm{sST}-25}$, or $0.16 \mathrm{mg} / \mathrm{ml} \mathrm{GST}$, and when included, $1 \mathrm{mM}$ sodium orthovanadate. Reaction mixes were incubated at $30^{\circ} \mathrm{C}$ and at the times indicated in the Figures; 5 $\mu \mathrm{l}$ aliquots were removed and diluted into an equal volume of $2 \mathrm{mM}$ vanadate and placed on ice. On completion of the time course, histone $\mathrm{H} 1$ kinase assays were performed as follows: the $10-\mu \mathrm{l}$ samples were added to $30 \mu$ l of kinase reaction mix to give a final concentration of $20 \mathrm{mM}$ HEPES, pH 7.5, $30 \mathrm{mM}$ B-mercaptoethanol, $0.1 \mathrm{mg} / \mathrm{ml} \mathrm{BSA}$ $10 \mathrm{mM} \mathrm{MgCl}_{2}, 0.1 \mathrm{mM}$ ATP, $80 \mathrm{mM}$ beta glycerol phosphate, PMSF, $\mathrm{AP}, \mathrm{LP}, \mathrm{PP}, 1 \mathrm{mM}$ vanadate, $0.2 \mu \mathrm{g}$ of protein kinase A inhibitor, 0.5 $\mathrm{mg}$ per $\mathrm{ml}$ histone $\mathrm{HI}, 1 \times 10^{7} \mathrm{cpm}$ gamma- ${ }^{32} \mathrm{P}$-ATP. Reactions were incubated at $30^{\circ} \mathrm{C}$ for $10 \mathrm{~min}$. Reactions were stopped by the addition of SDS sample buffer and were boiled at $100^{\circ} \mathrm{C}$ for $5 \mathrm{~min}$. Samples were resolved by SDS-PAGE on $12 \%$ gels. Labeled histone $\mathrm{H} 1$ was excised from each lane after staining gels with Coomassie blue, and radioactivity was measured by Cherenkov counting. In experiments using mutant proteins, $25 \mu \mathrm{l}$ of dilute prophase extracts (adjusted to $10 \mathrm{mM}$ creatine phosphate and $1 \mathrm{mM} \mathrm{ATP}$ ) was added directly to 25 $\mu \mathrm{l}$ of mutant cdc25 proteins (bound to glutathione beads) in phosphatase buffer (prepared as in Method 2).
Figure 1. Activation of MPF kinase activity by cdc25Hs protein. (A) Extracts were prepared from Xenopus oocytes as described in MATERIALS AND METHODS. Extracts were incubated for 0-40 min with buffer only (buffer), bacterially produced glutathione-S transferase (GST), or with p80 0 GST-cdc25 in the absence (GST25) or in the presence (GST-25+) of $1 \mathrm{mM}$ vanadate. At the indicated times, aliquots were removed and histone $\mathrm{H} 1$ kinase assays were performed in vitro. Reaction products were resolved by SDS-PAGE and analyzed by autoradiography. Exposure time was $45 \mathrm{~min}$ with an intensifying screen at $-80^{\circ} \mathrm{C}$. (B) Extracts were prepared from Xenopus oocytes as described in MATERIALS AND METHODS. p34 ${ }^{\text {cdc2 }}$ was immunoprecipitated with an antibody specific for Xenopus $\mathrm{p} 34^{\mathrm{cdc}}$. Immunoprecipitates were washed and then incubated for $40 \mathrm{~min}$ at room temperature with buffer only (lane 1), p80 8 CST-cdc25 (lane 2), p80 GST-cdc25 in the presence of $1 \mathrm{mM}$ vanadate (lane 3 ), glutathione-S-transferase (lane 4), or PTPIB (lane 5). Immune complex kinase assays were then performed in the presence of histone $\mathrm{H} 1$. Exposure time was for $5 \mathrm{~min}$ at room temperature. (C) Xenopus $\mathrm{p} 34^{\mathrm{cdc} 2}$ was immunoprecipitated as described above and incubated with PTP1B for $30 \mathrm{~min}$ at room temperature. Precipitates were then washed and incubated with buffer only

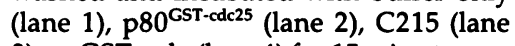
3), or GST only (lane 4) for $15 \mathrm{~min}$ at room temperature. Immune complex kinase assays were then performed with histone H1.

\section{Activation of MPF in Anti-p34 ${ }^{c d c 2}$ (Xenopus) Precipitates}

p34 ${ }^{\text {cdc2 }}$ was immunoprecipitated from $100 \mu$ l of dilute prophase extracts with $10 \mu$ l of Xenopus p34 $4^{\text {cdc2 }}$-specific antibody (antipeptide antiserum directed against the carboxy-terminal 12 amino acids of Xenopus p34 $4^{\text {cdc2 }}$ ) by incubation at $4^{\circ} \mathrm{C}$ for $2 \mathrm{~h}$ with gentle rocking. Protein $\mathrm{A}$ Sepharose was added and the incubation was continued for an additional hour. Immunoprecipitates were washed three times in MPF extraction buffer containing $1 \mathrm{mM}$ vanadate; three times in RIPA buffer (Parker et al., 1991) containing PMSF, AP, LP, PP, and $1 \mathrm{mM}$ vanadate; three times in lithium chloride wash buffer $(0.5 \mathrm{M}$ lithium chloride, $20 \mathrm{mM}$ Tris, pH 8.0, PMSF, AP, LP, PP, and $1 \mathrm{mM}$ vanadate); and two times with phosphatase buffer. The immunoprecipitates were then incubated with recombinant $\mathrm{p} 80^{\mathrm{GST}-25}(0.18 \mathrm{mg} / \mathrm{ml})$ or GST $(1.8$ $\mathrm{mg} / \mathrm{ml}$ ) protein in phosphatase buffer or PTP1B (final concentration of $0.013 \mathrm{mg} / \mathrm{ml}$ ). When included, vanadate was present at $1 \mathrm{mM}$. Reactions were incubated at room temperature for $1 \mathrm{~h}$ and the reaction was stopped by washing the beads two times in kinase wash buffer (20 mM HEPES, pH 7.5, $30 \mathrm{mM}$ B-mercaptoethanol, $0.1 \mathrm{mg} / \mathrm{ml} \mathrm{BSA}$, $10 \mathrm{mM} \mathrm{MgCl}_{2}, 80 \mathrm{mM}$ beta glycerol phosphate, PMSF, AP, LP, PP, and $1 \mathrm{mM}$ vanadate). Kinase assays were performed by the addition of $40 \mu \mathrm{l}$ of kinase reaction mix with final concentrations as described above. The reaction products were analyzed by SDS-PAGE and autoradiography as described above. In Figure 1C, precipitates were prepared and washed as described above and then incubated with PTP1B $(0.013 \mathrm{mg} / \mathrm{ml})$ for $30 \mathrm{~min}$ at room temperature. Precipitates were then washed three times with phosphatase buffer and incubated 
Figure 2. Bacterially produced cdc $25 \mathrm{Hs}$ protein induces meiotic maturation. (A) Lysates prepared from bacteria expressing either the glutathione S-transferase leader sequence from PGEX-2T (lane 1) or the cdc25-fusion protein from pML25 (lane 2) were prepared and incubated with glutathione-agarose beads as described in MATERIALS AND METHODS. The beads were washed and the bound proteins were eluted by boiling in SDS-sample buffer. Proteins were resolved by SDS-PAGE on a $12 \%$ gel and visualized by Coomassie blue staining. Species 1 and 2 are copurifying bacterial proteins and species 3 is a breakdown product of $\mathrm{p} 80^{\mathrm{GST}-\mathrm{ddc} 25}$. (B) Xenopus oocytes were incubated in progesterone in the absence $(\Lambda, n=25)$ or in the presence $(\square, n=17)$ of cycloheximide. Alternatively, oocytes were microinjected with $\mathrm{p} 80^{\mathrm{CST}-\mathrm{dd} 25}$ in the absence $(\bullet, n=23)$ or in the presence of cycloheximide $(O, n$ $=21$ ) or with bacterially produced glutathione S-transferase (GST, $\square, n=22$ ). Assay points for GST ( $\square$ ) remained at baseline throughout the 5-h incubation period. Values are expressed as percent of cells that had undergone GVBD at the time indicated.
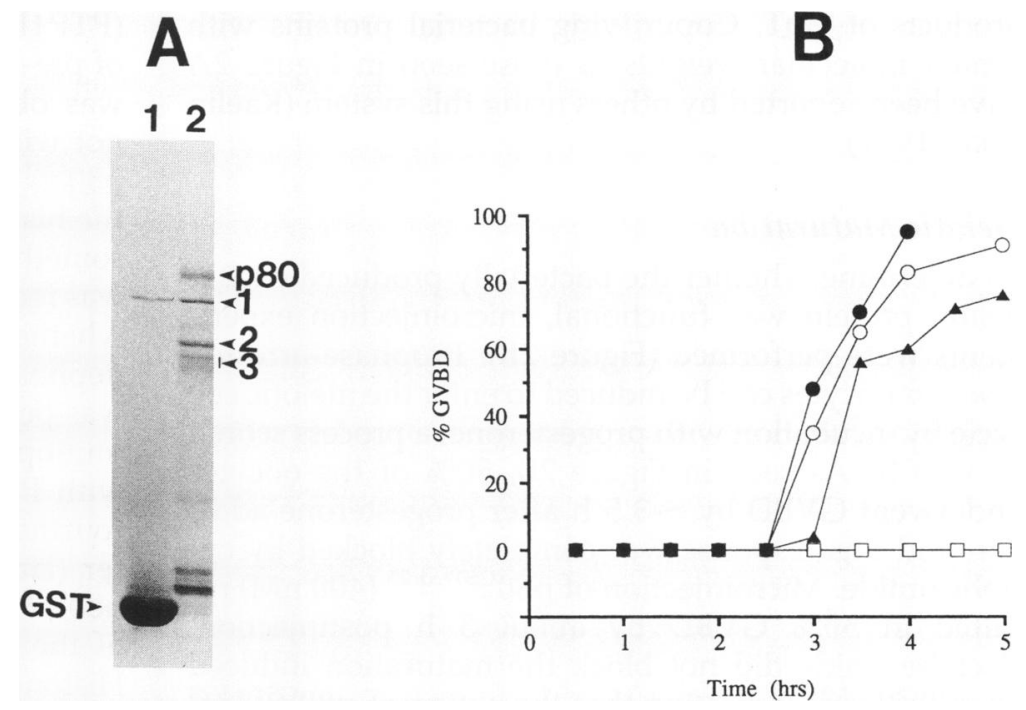

with p80 ${ }^{\text {GST-cdc25 }}(0.06 \mathrm{mg} / \mathrm{ml})$, C215 $(0.05 \mathrm{mg} / \mathrm{ml})$, GST $(0.85 \mathrm{mg} /$ $\mathrm{ml}$ ), or buffer alone for $15 \mathrm{~min}$ at room temperature. Histone $\mathrm{H} 1$ kinase assays were then performed as described above and the reaction products were analyzed by SDS-PAGE and autoradiography.

\section{Purification of Phosphotyrosine-Containing Form of p34 ${ }^{\text {cdc2 }} /$ Cyclin Complex From Overproducing Insect Cells}

p34 $4^{\text {cdc2 }}$ phosphorylated on tyrosine 15 was produced using a baculoviral expression system as described previously (Parker et al., 1991). Ten $\times 10^{6}$ Sf 9 cells were seeded onto $100-\mathrm{mm}$ tissue culture dishes. After attachment, cells were coinfected with recombinant viruses encoding human $\mathrm{p} 34^{\mathrm{dec} 2}$, clam cyclin B, and S. pombe p107wee1, each at multiplicity of infection of $\sim 10$. At $37 \mathrm{~h}$ postinfection, plates were rinsed once with methionine-free Graces media (GIBCO) followed by incubation at $26^{\circ} \mathrm{C}$ for $3 \mathrm{~h}$ in $1.2 \mathrm{ml} \mathrm{Graces}$ methionine-free media supplemented with $2 \mathrm{mM}$ glutamine, $1.5 \%$ dialyzed calf serum, and $500 \mu \mathrm{Ci} / \mathrm{ml}^{35} \mathrm{~S}$-Trans label (ICN Biomedicals Inc., Costa Mesa, CA). After the incubation period, cells were rinsed twice with PBS and then were lysed in $1.3 \mathrm{ml}$ of cdc2 lysis buffer $(50 \mathrm{mM}$ Tris, $\mathrm{pH} 7.4$, $0.1 \%$ vol/vol NP-40, $50 \mathrm{mM} \mathrm{NaF}, 10 \mathrm{mM} \mathrm{NaPPi}, 250 \mathrm{mM} \mathrm{NaCl}$, PMSF, AP, LP, and $1 \mathrm{mM}$ sodium vanadate) at $4^{\circ} \mathrm{C}$ for $15 \mathrm{~min}$. Lysates were centrifuged at $10000 \times g$ for $10 \mathrm{~min}$. Supernatants were collected and the $\mathrm{p} 34^{\mathrm{ccc}} /$ cyclin $\mathrm{B}$ complex was precipitated using either a polyclonal antibody against human $\mathrm{p} 34^{\mathrm{dcc} 2}$ or $\mathrm{p} 13^{\text {suc1 }}$ beads as described previously (Parker et al., 1991).

\section{Phosphatase Assays}

p34 ${ }^{\text {odc2 }}$ phosphorylated on tyrosine 15 was purified from Sf9 cells using either p34 ${ }^{\text {cdc2 }}$-specific antibody coupled to protein A Sepharose or $\mathrm{p} 13^{\text {suc } 1}$ beads. The beads were washed four times with phosphatase buffer. After the final wash, $200 \mu l$ of phosphatase buffer containing bacterially produced recombinant protein at a concentration of 60 $\mathrm{ng} / \mu \mathrm{l}$ (isolated by Method 2) was added. Tubes were incubated at $25^{\circ} \mathrm{C}$ and at the times indicated in the Figures; $100-\mu \mathrm{l}$ aliquots were removed and added to $500 \mu \mathrm{l}$ of cdc2 lysis buffer containing $2 \mathrm{mM}$ vanadate. The reaction mixes were centrifuged at $1000 \times g$ for $1 \mathrm{~min}$ and the supernatant was discarded. The pelleted beads were boiled in SDS sample buffer and proteins were resolved by SDS-PAGE and visualized by autoradiography.

\section{PNPP Assays}

Recombinant protein bound to glutathione beads was prepared by Method 2 except that beads were washed once with PNPP wash buffer (50 mM Tris, pH 7.4, 0.1\% vol/vol B-mercaptoethanol, AP, $\mathrm{PP}, \mathrm{LP}$, and PMSF) rather than phosphatase buffer. Assays were performed by adding $500 \mu \mathrm{l}$ of reaction buffer (PNPP wash buffer containing $20 \mathrm{mM}$ PNPP) to the recombinant protein and incubating the mixture at room temperature with gentle rocking. At the indicated time points, the reaction was stopped by addition of $500 \mu \mathrm{l}$ of $0.5 \mathrm{M}$ $\mathrm{NaOH}$. Absorbance at $410 \mathrm{~nm}$ was measured using a Beckman DU7 spectrophotometer (Beckman, Fullerton, CA). Units were calculated by determining the slope of the standard curve (in OD units $/ \mathrm{min}$ ) and using it in the equation (slope) $/\left(1.75 \times 10^{4} \mathrm{~mol} \cdot \mathrm{cm}^{-1} \cdot \mathrm{ml}^{-1}\right)$. Specific activity is expressed as units ( $U=$ pmole PNPP hydrolyzed/ $\mathrm{min}$ ) per $\mathrm{mg}$ of recombinant protein.

\section{RESULTS}

\section{Protein Production}

To facilitate the production and purification of the human cdc 25 gene product, a bacterial expression vector was constructed that expressed the full length cdc $25^{+}$ gene product as a fusion protein with the Schistosoma japonicum GST gene. The majority of the $80-\mathrm{kDa}$ cdc 25 fusion protein (p80 ${ }^{\mathrm{GST}-\mathrm{cdc} 25}$ ) was present in the insoluble fraction of the bacterial lysate; however, the soluble fraction $(\sim 1 \%)$ was easily purified by affinity chromatography on glutathione coupled to agarose (Figure $2 \mathrm{~A}$, lane 2). As seen in lane 1, GST migrated with a molecular weight of $\sim 26 \mathrm{kDa}$. Also evident in lanes 1 and 2 is an endogenous bacterial protein of $\sim 70 \mathrm{kDa}$ (species 1) that copurified with GST and p80 $0^{\mathrm{GST}-\mathrm{cdc} 25}$ (also see Figure 5B). Another bacterial protein of $\sim 60 \mathrm{kDa}$ (species 2, lane 2) copurified with p80 ${ }^{\mathrm{GST}-\mathrm{cdc} 25}$ (see Figure 5B). Species 3 was generated during the purification of p80 $0^{\text {GST-cdc25 }}$, was recognized by an antibody specific for the cdc 25 protein, and thus is likely to be a degradation product of $\mathrm{p} 80^{\mathrm{GST}-\mathrm{cdc} 25}$. Smaller species of $27-30 \mathrm{kDa}$ were also detected and may represent read-through 
products of GST. Copurifying bacterial proteins with similar molecular weights to those seen in Figure 2A have been reported by others using this system (Kaelin et al., 1991).

\section{Meiotic Maturation}

To determine whether the bacterially produced cdc25fusion protein was functional, microinjection experiments were performed (Figure 2B). Prophase-arrested Xenopus oocytes can be induced to enter the meiotic cell cycle by incubation with progesterone, a process scored by GVBD. As seen in Figure 2B, 50\% of the oocytes underwent GVBD by $\sim 3.5 \mathrm{~h}$ after progesterone addition and this response was completely blocked by cycloheximide. Microinjection of p80 8 GST-cdc25 $(400 \mathrm{nM})$ resulted in $50 \%$ GVBD by about $3 \mathrm{~h}$ postinjection. Cycloheximide did not block the maturation induced by $\mathrm{p} 80^{\mathrm{GST}-\mathrm{cdc} 25}$ indicating that the action of $\mathrm{p} 80^{\mathrm{GST}-\mathrm{cdc} 25}$ was independent of new protein synthesis. Bacterially expressed GST (control) did not induce GVBD under similar assay conditions.

\section{Activation of pre-MPF in vitro}

The role of cdc25 protein in the activation of pre-MPF was further investigated in extracts prepared from stage VI oocytes (Figure 1A). Addition of p80 8 GST-cdc25 (at a final concentration of $\sim 500 \mathrm{nM}$ ) to extracts stimulated histone HI kinase activity (GST-25) sixfold within 20 $\mathrm{min}$. In the absence of an ATP-regenerating system the activation process was delayed, requiring $60 \mathrm{~min}$ to reach the sixfold increase. The activation by $\mathrm{p} 80^{\text {GST-cdc25 }}$ was inhibited by the protein-tyrosine phosphatase inhibitor sodium orthovanadate (GST-25+), suggesting the involvement of a tyrosine-specific protein phosphatase in the activation process. Buffer alone or bacterially expressed GST had no effect on the kinase activity of pre-MPF in the extract.

These results suggested that the bacterially produced cdc25-fusion protein was capable of activating pre-MPF in intact oocytes as well as in extracts prepared from oocytes and that the activation was dependent, at least in part, on the activity of a tyrosine-specific protein phosphatase. To look more directly at the effects of p80 ${ }^{\mathrm{GST} \text {-cdc25 }}$ on pre-MPF, immunoprecipitation experiments were performed. p34 ${ }^{\text {cdc2 }} /$ cyclin complexes (preMPF) were immunoprecipitated from oocyte extracts using an antibody specific for Xenopus $\mathrm{p} 34^{\mathrm{cdc} 2}$. The immunoprecipitates were stringently washed with RIPA buffer and $0.5 \mathrm{M} \mathrm{LiCl}$ and were then assayed for their ability to be activated under a variety of conditions. As seen in Figure 1B (lane 2), p80 ${ }^{\text {GST-cdc25 }}$ activated the histone $\mathrm{H} 1$ kinase activity of pre-MPF in vitro 15 -fold over controls (buffer only, lane 1) when added to the immunoprecipitates. The activation of pre-MPF by p80 $0^{\text {GST-cdc25 }}$ was inhibited by vanadate (lane 3 ). Neither GST (lane 4) nor human placental phosphatase 1B
(PTP1B, lane 5) activated the histone $\mathrm{H} 1$ kinase activity of pre-MPF. The tyrosine dephosphorylation of $\mathrm{p} 34^{\text {cdc2 }}$ was observed with both $\mathrm{p} 80^{\mathrm{GST}-\mathrm{cdc} 25}$ and PTP1B but not with GST or when vanadate was included in the p80 ${ }^{\mathrm{GST}-c d c 25}$ reaction. The failure of PTP1B to activate the histone $\mathrm{H} 1$ kinase activity of $\mathrm{p} 34^{\mathrm{cdc} 2}$ suggested that something in addition to tyrosine dephosphorylation was required for the activation of $\mathrm{p} 34^{\mathrm{cdc} 2}$. To determine whether $\mathrm{p} 80^{\mathrm{GST}-\mathrm{cdc} 25}$ could activate $\mathrm{p} 34^{\text {cdc2 }}$ that had been dephosphorylated by PTP1B, the following experiment was performed (Figure 1C). p34 ${ }^{\text {cdc2 }}$ (pre-MPF) was immunoprecipitated from Xenopus extracts and incubated with PTP1B. The reaction mix was then divided into fourths. The aliquots were either incubated with buffer (lane 1), p80 8 GT-cdc25 (lane 2), C215, a mutant of p80 ${ }^{\text {GST-cdc25 }}$ containing the C-terminal 215 amino acids of the protein (see below), (lane 3), or GST (lane 4). Histone $\mathrm{H} 1$ kinase assays were then performed. As shown in Figure 1C, incubation of the immunoprecipitates with either $\mathrm{p} 80^{\mathrm{GST}-\mathrm{cdc} 25}$ or the mutant $\mathrm{C} 215$ (but not with either buffer or GST) resulted in the activation of $\mathrm{p} 34^{\mathrm{cdc} 2}$.

\section{Tyrosine-Dephosphorylation of Insect Cell-Derived p34 ${ }^{\text {cdc2 }}$}

We have previously demonstrated that $\mathrm{p} 34^{\mathrm{cdc} 2}$ is phosphorylated on tyrosine 15 when coproduced with cyclin and the wee $1^{+}$gene product in insect cells using a baculoviral expression system (Parker et al., 1991). The tyrosine phosphorylated form of $\mathrm{p} 34^{\mathrm{cdc} 2}$ has a slower electrophoretic mobility than other forms of $\mathrm{p} 34^{\text {cdc2 }}$ and can therefore be distinguished by SDS-PAGE (Figure $3 \mathrm{~A})$. We used the insect-derived $\mathrm{p} 34^{\text {cdc2 }} /$ cyclin complex as an independent assay for monitoring $\mathrm{p} 80^{\mathrm{GST}-\mathrm{cdc} 25}$ function. The validity of this assay is demonstrated in Figure 3A. ${ }^{35} \mathrm{~S}$-labeled $\mathrm{p} 34^{\text {cdc2 }} /$ cyclin complexes were immunoprecipitated (using anti-p34 ${ }^{\text {cdc2 }}$ serum) from lysates derived from cells coproducing $\mathrm{p} 34^{\mathrm{cdc} 2}$, cyclin $\mathrm{B}$, and $p 107^{\text {weel }}$. As seen in Figure $3 A$ (left), cyclin B as well as 2 forms of p34 ${ }^{\text {cdc2 }}$ (differing in electrophoretic mobility) are evident. Only the slower electrophoretic form of p34 ${ }^{\mathrm{cdc} 2}$ reacted with an anti-phosphotyrosine antibody (right). Incubation of the immunoprecipitates with bacterially produced placental phosphatase 1B (PTP1B) (Chernoff et al., 1990) resulted in the tyrosine dephosphorylation of $\mathrm{p} 34^{\mathrm{cdc} 2}$ as monitored by the disappearance of the slower electrophoretic form of $\mathrm{p} 34^{\text {cdc2 }}$ (left, lane 3) coincident with the loss in immunoreactivity with the anti-phosphotyrosine antibody (right, lane 3 ).

The ability of bacterially derived $\mathrm{p} 80^{\mathrm{GST}-\mathrm{ccc} 25}$ to cause the tyrosine dephosphorylation of $\mathrm{p} 34^{\mathrm{cdc} 2}$ was tested using this assay. As seen in Figure 3B, addition of p80 ${ }^{\text {cST-cdc25 }}$ to $\mathrm{p}^{13^{\text {suc1 }}}$ precipitates of ${ }^{35} \mathrm{~S}$-labeled $\mathrm{p} 34^{\text {cdc2 }} /$ cyclin complexes stimulated the tyrosine dephosphorylation of $\mathrm{p} 34^{\mathrm{cdc} 2}$, as monitored by the loss of the slower electrophoretic form of $\mathrm{p} 34^{\mathrm{cdc} 2}$ (lanes 4-6). Vanadate 
A

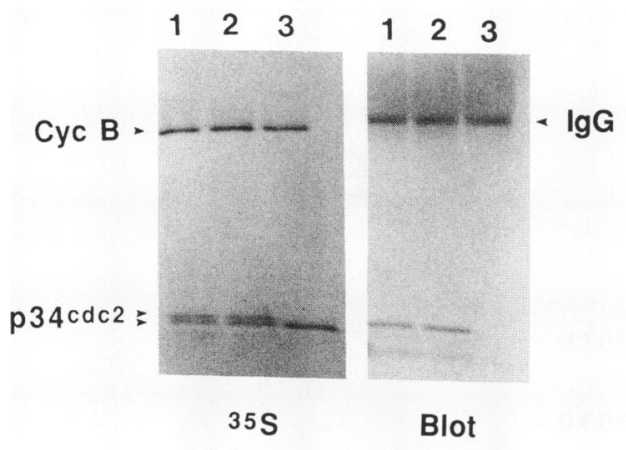

B

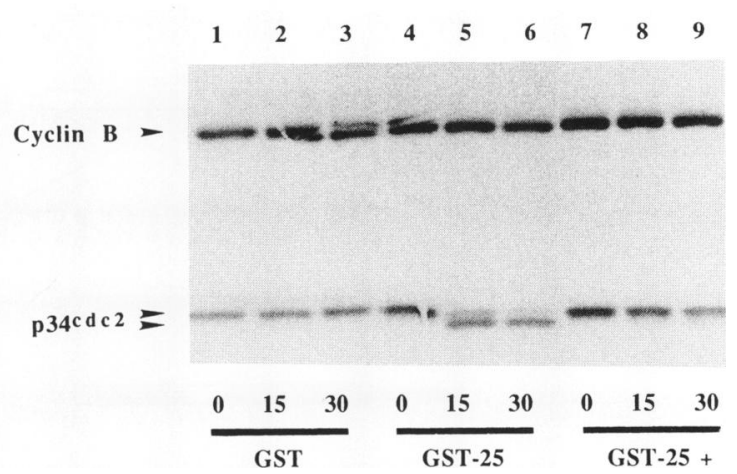

Figure 3. Tyrosine-dephosphorylation of $\mathrm{p} 34^{\mathrm{cdc} 2}$ produced in insect cells. (A) ${ }^{35} \mathrm{~S}$-labeled $\mathrm{p} 34^{\mathrm{cdc} 2} / \mathrm{cyclin}$ complexes were immunoprecipitated (using anti-p34 ${ }^{\text {ddc2 }}$ serum) from insect cells coproducing $\mathrm{p} 34^{\text {cdc2 }}$, cyclin $\mathrm{B}$, and $\mathrm{p} 107^{\text {weel }}$ as described in MATERIALS AND METHODS. Immunoprecipitates were divided into thirds. One-third was left untreated (lane 1), one-third was incubated in phosphatase buffer alone (lane 2), and the final third was incubated with PTB1B (lane 3). Proteins were resolved by SDS-PAGE, blotted onto nitrocellulose, and probed with a monoclonal antibody directed against phosphotyrosine (right). The blot was then exposed to film and ${ }^{35} \mathrm{~S}$-labeled proteins were detected by autoradiography (left). (B) ${ }^{35}$ S-labeled p34 ${ }^{\text {dc2 }} /$ cyclin complexes were precipitated from insect cells coproducing p $34^{\mathrm{cdc} 2}$, cyclin B, and p107 $7^{\text {weel }}$ using $\mathrm{p} 13^{\text {sucl }}$ beads. The precipitates were divided into thirds. One-third was incubated with GST (lanes 1-3), one-third was incubated with the p80 $0^{\mathrm{GST}-\mathrm{cdc} 25}$ (lanes 4-6), and the final third was incubated with $\mathrm{p} 80^{\mathrm{GST}-\mathrm{cdc} 25}$ and $1 \mathrm{mM}$ vanadate (lanes 7-9). Aliquots were collected at 0 , 15 , and $30 \mathrm{~min}$ and analyzed by SDS-PAGE and autoradiography.

blocked the $\mathrm{p} 80^{\mathrm{GST}-\mathrm{cdc} 25}$-dependent dephosphorylation of p34 cdc2 (GST-25+, lanes 7-9), and GST was negative in this assay (GST, lanes 1-3). Identical results were obtained when the $\mathrm{p} 34^{\mathrm{cdc} 2} /$ cyclin complex was immunoprecipitated with anti-p34 $4^{\text {cdc2 }}$ sera rather than with p13 $3^{\text {suc1 }}$ beads.

\section{The C Terminus of cdc25Hs Possesses Intrinsic Phosphatase Activity}

The cdc $25 \mathrm{Hs}$ protein consists of 473 amino acids. Regions of homology with other cdc25 homologs are localized within the $C$ terminus (residues 245-473) of cdc25Hs (Edgar and O'Farrell, 1989; Russell et al., 1989; Jimenez et al., 1990; Sadhu et al., 1990). To localize the structural domain of the cdc25 protein required for function, a series of amino- and carboxy-terminal deletion mutants of $\mathrm{p} 80^{\mathrm{GST}-\mathrm{cdc} 25}$ were constructed and expressed in bacteria as fusion proteins (Figure 4). The mutant proteins were tested for their ability to activate histone $\mathrm{H} 1$ kinase activity in extracts prepared from Xenopus oocytes (Figure 5A), for their ability to stimulate the tyrosine-dephosphorylation of insect-cell derived p34 ${ }^{\mathrm{cdc} 2}$ in vitro (Figure 5B), and for their ability to hydrolyze PNPP (Figure 6).

As seen in Figure 4B, recombinant fusion proteins of the expected molecular weights were easily purified from induced bacteria using glutathione beads. As was seen in Figure 2A, a 70-kDa bacterial protein (species 1) copurified with GST as well as with each of the cdc25fusion proteins, with the exception of C173 (lane 7). C173 was constructed in vector PGEX-1, whereas all the other mutants were constructed in vector PGEX-2T. Interestingly, pGEX-2T differs from pGEX-1 in that it encodes for a thrombin cleavage site and this may be the region involved in binding to p70. Species $2(60-$ $\mathrm{kDa}$ bacterial protein) copurified with $\mathrm{p} 80^{\mathrm{GST}-\mathrm{cdc} 25}$ as well as the deletion mutants of cdc25 that retained the carboxy-terminal domain (lanes 1-3, 6, and 7). However, copurification of species 2 did not correlate with cdc25 function (see below).

As shown in Figure 5, the activities of each of the mutant proteins were tested in two distinct assays: activation of Xenopus pre-MPF in prophase extracts (A) and tyrosine dephosphorylation of $\mathrm{p} 34^{\mathrm{cdc} 2}$ produced in insects cells (B). As seen in Figure 5A and B, the Cterminal deletion mutants of cdc25Hs (N300 and N258) were negative in both assays, whereas mutant C215 that completely lacked the $\mathrm{N}$-terminus of cdc $25 \mathrm{Hs}$ but retained C-terminal residues $258-473$ was fully functional. Deletion mutants N459 and N435 that lack the C-terminal 14 and 37 amino acids, respectively, were also fully functional in both assays. These results point to the importance of the conserved C-terminal domain of cdc $25 \mathrm{Hs}$ for function. $\mathrm{C} 173$, a slightly larger deletion mutant than C215 (retains residues 301-473), was negative in both assays. Thus, sequences located between residues 258 and 301 are essential for cdc25Hs function. As mentioned above, species 2 (60-kDa bacterial protein) copurified with $\mathrm{p} 80^{\mathrm{GST}}$-cdc25 in addition to each of the mutants that retained the $C$ terminus of the cdc25 protein (lanes 1-3, 6, and 7). However, binding of p60 to p80 $0^{\mathrm{GST}-\mathrm{cdc} 25}$ did not correlate with function as mutant C173 (lane 7) bound p60 yet was nonfunctional in the 


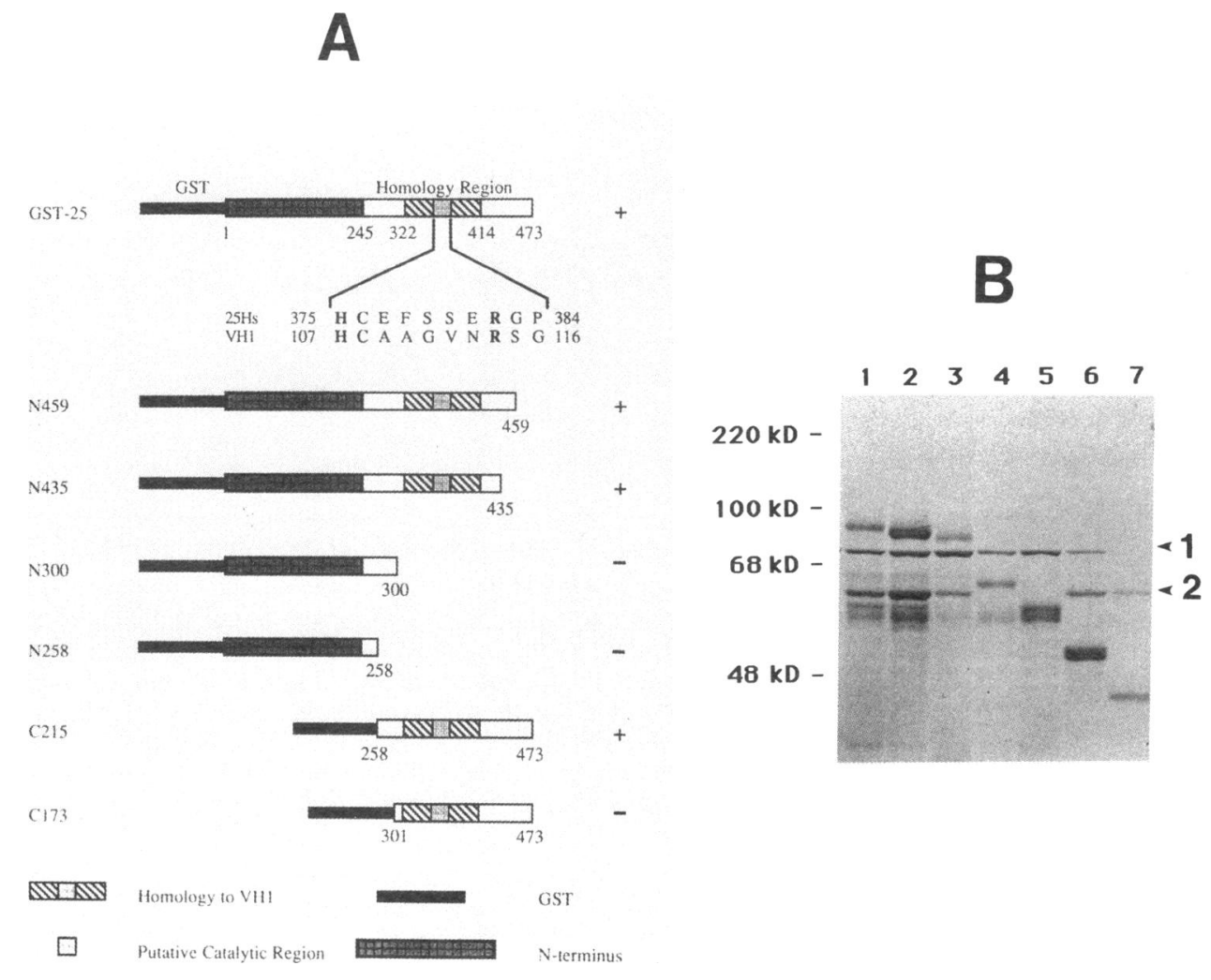

Figure 4. Expression and purification of deletion mutants of cdc25Hs protein. (A) Structure of glutathione S-transferase fusion proteins. $(+)$ indicates that the protein was functional; $(-)$ indicates that the mutant protein was nonfunctional. (B) Lysates prepared from bacteria expressing

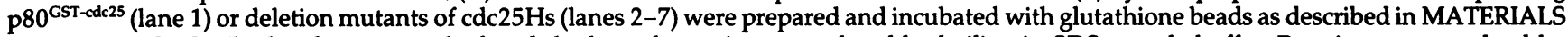
AND METHODS. The beads were washed and the bound proteins were eluted by boiling in SDS-sample buffer. Proteins were resolved by SDS-PAGE on a 12\% gel and were visualized by Coomassie blue staining. N459 (lane 2), N435 (lane 3), N300 (lane 4), N258 (lane 5), C215 (lane 6), C173 (lane 7). Species 1 and 2 are copurifying bacterial proteins.

assays performed in this study. These results suggest that the functional domain of the cdc25Hs protein resides within its $C$ terminus between residues 258 and 435 .

To further purify the cdc25Hs assay system, GST,

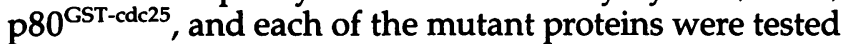
for their ability to hydrolyze PNPP, a commonly used artificial substrate for monitoring tyrosine-specific protein phosphatase activity. Using standard assay conditions for measuring PNPP hydrolysis by tyrosinespecific protein phosphatases, GST and mutants C173, N300, and N258 were negative (at the $40-\mathrm{min}$ time point, the OD units were $<0.01$ ). However, mutant C215 hydrolyzed PNPP at a significant rate under similar assay conditions (Figure 6). We calculated the specific activity of C215 to be $\sim 300$ units $/ \mathrm{mg}$ of recombinant protein compared with 3600 units $/ \mathrm{mg}$ for bacterially produced PTP1B (Figure 6B). For reasons that are not understood, the solubility of bacterially produced C215 protein is much greater than that of $\mathrm{p} 80^{\mathrm{GST}-\mathrm{cdc} 25}$ or the other mutant proteins. When compared over a concentration range from 0.1 to $1 \mu \mathrm{g}$ of protein, C215, p80 8 GT-cdc25, N459, and N435 were found to be indistinguishable in their ability to hydrolyze PNPP.

\section{DISCUSSION}

To study the contribution made by the cdc $25 \mathrm{Hs}$ protein to the regulation of $\mathrm{p} 34^{\mathrm{cdc} 2}$, we have overproduced the cdc $25 \mathrm{Hs}$ protein as well as several deletion mutants of cdc $25 \mathrm{Hs}$ in bacteria. The recombinant proteins were assayed for function in three independent systems: 1) Xenopus oocytes were used to monitor the ability of recombinant cdc 25 protein to induce meiotic maturation as well as to activate p34 $4^{\text {cdc2 }}$ (both in extracts and in immunoprecipitates); 2) recombinant cdc $25 \mathrm{Hs}$ protein was monitored for its ability to dephosphorylate $\mathrm{p} 34^{\mathrm{cdc} 2}$ (on tyrosine 15), that had been isolated from overproducing insect cells using a baculoviral expression system; and 3) recombinant cdc $25 \mathrm{Hs}$ protein was assayed using PNPP as an artificial substrate. Results from each of these systems suggest that the cdc $25 \mathrm{Hs}$ protein pos- 


\section{A: Xenopus p34cdc2}

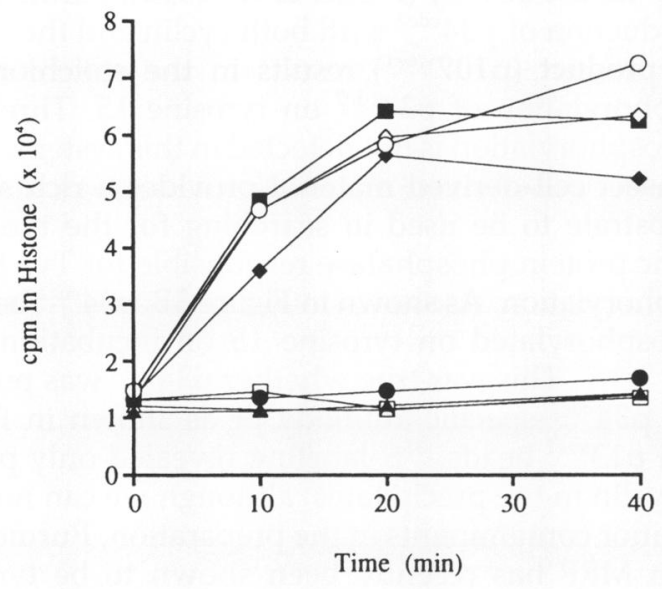

\section{B: Insect-cell derived p34cdc2}

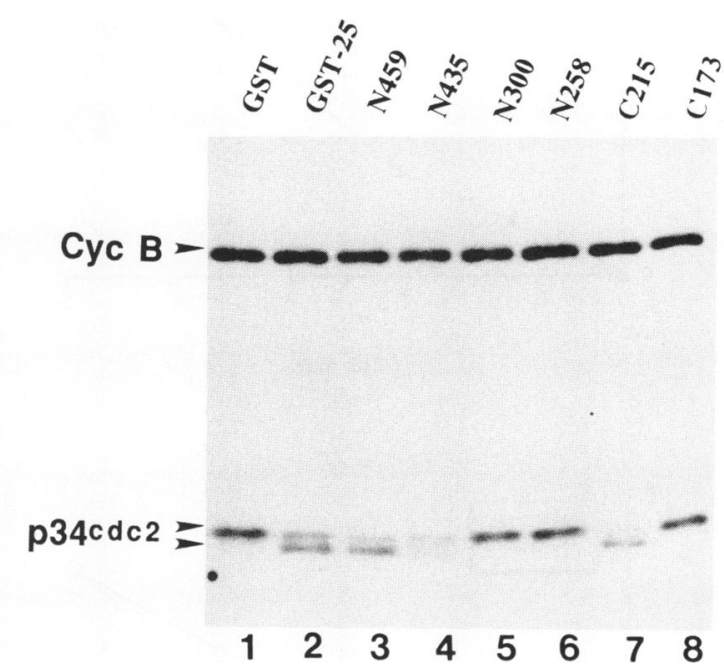

Figure 5. The $\mathrm{C}$ terminus of the cdc25 protein is required for function. (A) Extracts were prepared from Xenopus oocytes as described in MATERIALS AND METHODS. Extracts were incubated with bacterially produced proteins bound to glutathione beads and at the times indicated $(0,10,20$, and $40 \mathrm{~min})$, aliquots were removed, and histone $\mathrm{H} 1$ kinase assays were performed. Reaction products were resolved by SDS-PAGE and analyzed by autoradiography. Histone $\mathrm{H} 1$ was excised from the gel and quantitated by Cerenkov counting. Results are

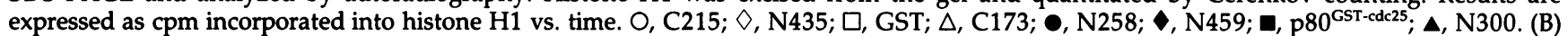
${ }^{35} \mathrm{~S}$-labeled $\mathrm{p} 34^{\text {cdc2 }} /$ cyclin complexes were precipitated from insect cells coproducing $\mathrm{p} 34^{\text {cdc2 }}$, cyclin B, and p107 10 wee1 using p13 ${ }^{\text {suc1 }}$ beads. The precipitates were divided equally and incubated with the following recombinant proteins bound to glutathione beads: glutathione S-transferase (GST, Lane 1), p80 $0^{\mathrm{GST}-\mathrm{cdc25}}$ (lane 2), N459 (lane 3), N435 (lane 4), N300 (lane 5), N257 (lane 6), C215 (lane 7 ), or C173 (lane 8). After 90 min, samples were boiled in the presence of SDS and analyzed by SDS-PAGE and autoradiography.

sesses intrinsic phosphatase activity and that it functions as a positive regulator of the cell cycle by dephosphorylating $\mathrm{p} 34^{\text {cdc2 }}$.

Bacterially produced cdc $25 \mathrm{Hs}$ protein-induced meiotic maturation of Xenopus oocytes in the absence of protein synthesis. Over the course of this study, 464 oocytes were injected with $2-32 \mathrm{ng}$ of $\mathrm{p} 80^{\mathrm{GST}-\mathrm{cdc} 25}$ (final concentrations varied between 22 and $400 \mathrm{nM}$ ). The time for $50 \%$ GVBD varied between experiments from 2.5 to $5 \mathrm{~h}$ but consistently occurred $1 \mathrm{~h}$ before that induced by progesterone. This response is slower than that seen when the cyclins are microinjected into oocytes (Swenson et al., 1986; Westendorf et al., 1989; Roy et al., 1991). This difference may be due to the fact that p80 ${ }^{\mathrm{GST}-c d c 25}$ acts on preassembled pre-MPF whereas there is a recruitment of more $\mathrm{p} 34^{\mathrm{cdc} 2}$ by the microinjected cyclins that amplifies the response. Alternatively, bacterially produced $\mathrm{p} 80^{\mathrm{GST}-\mathrm{cdc} 25}$ may lack some posttranslational modification required for maximal activity. p80 ${ }^{\text {GST-cdc25 }}$ activated pre-MPF when added to extracts prepared from G2/prophase-arrested Xenopus oocytes. The activation, measured as phosphate incorporation into exogenously added histone $\mathrm{H} 1$, varied between four- and eightfold. The inclusion of an ATP-regenerating system decreased the time required for the cdc $25 \mathrm{Hs}$-dependent activation but not the amplitude of the response. Sodium vanadate, an inhibitor of known phosphotyrosine-specific protein phosphatases, inhibited the cdc25Hs-dependent activation. The results reported in this study using the human cdc 25 protein in Xenopus oocyte extracts are similar to those reported using the Drosophilia cdc25 homolog (string) (Kumagai and Dunphy, 1991).

Microinjection of cdc25Hs protein into intact oocytes and addition of cdc $25 \mathrm{Hs}$ protein to whole-cell extracts were both crude assay systems. To further purify the assay system, pre-MPF was immunopurified from Xenopus oocyte extracts using an antibody specific for Xenopus $\mathrm{p} 34^{\mathrm{cdc} 2}$. The immunoprecipitates were then stringently washed using both RIPA buffer and $0.5 \mathrm{M} \mathrm{LiCl}$ and were used to test for the ability of recombinant cdc $25 \mathrm{Hs}$ protein to activate the histone $\mathrm{H} 1$ kinase activity of p34 ${ }^{\text {cdc2 }}$. As seen in Figure $1 \mathrm{~B}, \mathrm{p} 80^{\mathrm{GST}-\mathrm{cdc} 25}$ activated the histone $\mathrm{H} 1$ kinase activity of $\mathrm{p} 34^{\text {cdc2 }} 15$-fold over background. Sodium vanadate inhibited the cdc $25 \mathrm{Hs}$-dependent activation indicating that tyrosinedephosphorylation was required at least in part for the activation. However, tyrosine dephosphorylation was not the only requirement as PTP1B catalyzed the tyrosine dephosphorylation of $\mathrm{p} 34^{\mathrm{cdc} 2}$ but did not detectably activate its histone $\mathrm{H} 1$ kinase activity. Interestingly, p80 ${ }^{\mathrm{GST} \text {-cdc25 }}$ was capable of activating the tyrosine-dephosphorylated form of $\mathrm{p} 34^{\mathrm{cdc} 2}$ (Figure 1C). That tyrosine dephosphorylation is not sufficient for activation 

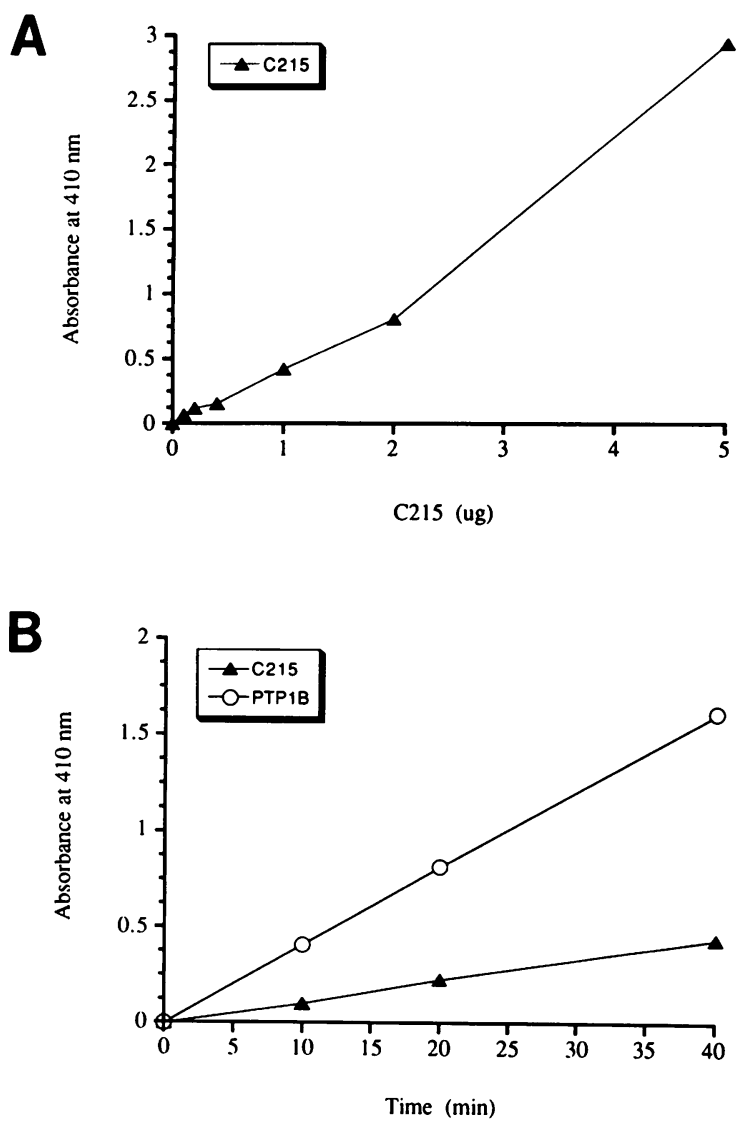

Figure 6. Hydrolysis of PNPP by cdc25Hs protein. (A) PNPP assays were performed as described in MATERIALS AND METHODS. Varying amounts of C215 mutant protein were incubated with PNPP for $45 \mathrm{~min}$ at which time the reaction was stopped by the addition of $\mathrm{NaOH}$ and absorbance at $410 \mathrm{~nm}$ was measured. (B) Recombinant C215 protein $(2 \mu \mathrm{g})$ and PTP1B $(0.63 \mu \mathrm{g})$ were incubated with PNPP as described in MATERIALS AND METHODS. At the times indicated the reactions were terminated and absorbance at $410 \mathrm{~nm}$ was measured.

has been reported for human $\mathrm{p} 34^{\mathrm{cdc} 2}$ as well (Morla et al., 1989). One explanation for the activation observed with $\mathrm{p} 80^{\mathrm{GST}-\mathrm{cdc} 25}$ but not with PTP1B is that the cdc25Hs protein may function in the dephosphorylation of p3 $34^{\text {cdc2 }}$ on both threonine 14 and tyrosine 15 .

The cdc 25 protein has been reported to be a phosphoprotein but the role of phosphorylation in regulating the cdc25 protein has not been defined. However, because bacterially produced cdc $25 \mathrm{Hs}$ protein was functional in the immune complex kinase assays (in the absence of ATP), phosphorylation must not be an absolute requirement for activity. The assays reported in this study should facilitate determining the contribution made by phosphorylation to the activity of the cdc $25 \mathrm{Hs}$ protein.

As an independent means of assaying cdc $25 \mathrm{Hs}$ function, we used a baculoviral expression system to overproduce the tyrosine 15-phosphorylated form of p34 ${ }^{\mathrm{cdc} 2}$.
We have previously reported that coproduction of $\mathrm{p} 34^{\mathrm{cdc} 2}$ with cyclin in insect cells results in the formation of functional $\mathrm{p} 34^{\mathrm{cdc} 2} /$ cyclin complexes as judged by coprecipitation, cyclin phosphorylation, and activation of p34 $4^{\text {cdc2 }}$ kinase activity (Parker et al., 1991). Furthermore, coproduction of $\mathrm{p} 34^{\mathrm{cdc} 2}$ with both cyclin and the wee $1^{+}$ gene product ( $\mathrm{p} 107^{\mathrm{wee}}$ ) results in the stoichiometric phosphorylation of $\mathrm{p} 34^{\text {cdc2 }}$ on tyrosine 15 . Threonine 14 phosphorylation is not detected in this system. Thus, the insect cell-derived material provides a rich source of substrate to be used in searching for the tyrosinespecific protein phosphatase responsible for Tyr 15 dephosphorylation. As shown in Figure 3B, p34 $4^{\text {cdc2 }}$ became dephosphorylated on tyrosine 15 on incubation with $\mathrm{p} 80^{\mathrm{GST}-\mathrm{cdc} 25}$. This was true whether $\mathrm{p} 34^{\mathrm{cdc} 2}$ was purified using p34 ${ }^{\text {cdc2 }}$-specific antibody or as shown in Figure $3 \mathrm{~B}$ on $\mathrm{p} 13^{\text {suc } 1}$ beads. ${ }^{35} \mathrm{~S}$-labeling revealed only $\mathrm{p} 34^{\text {cdc2 }}$ and cyclin in the precipitates, although we can not rule out minor contaminants in the preparation. Purified sea urchin MPF has recently been shown to be tyrosine dephosphorylated and activated on incubation with bacterially produced cdc $25 \mathrm{Hs}$ protein (Strausfeld et al., 1991).

Unlike $\mathrm{p} 34^{\mathrm{cdc} 2}$ isolated from Xenopus oocytes, we were unable to detect any activation of insect cell-derived p34 ${ }^{\text {cdc2 }}$ coincident with its tyrosine dephosphorylation. As previously published, the tyrosine phosphorylated form of $\mathrm{p} 34^{\mathrm{cdc} 2}$ produced in insect cells (on coproduction of p34 $4^{\text {cdc2 }}$ with cyclin and p107 ${ }^{\text {wee1 }}$ ) lacks any appreciable threonine phosphorylation (Parker et al., 1991). Thus, the activating threonine phosphorylation (presumably threonine 161) may be absent in this population of $\mathrm{p} 34^{\mathrm{cdc} 2}$ and could account for the apparent lack of activation.

To identify the minimal domain of cdc $25 \mathrm{Hs}$ capable of functioning in these assays, a series of $\mathrm{N}$ - and Cterminal mutants of the cdc $25 \mathrm{Hs}$ protein were constructed. We identified a region in the $C$ terminus of the cdc $25 \mathrm{Hs}$ protein (bordered by amino acids 258 and 435 ) that was fully functional. Thus, the amino terminus of cdc $25^{+}$, at least in these assays, was completely dispensible for function. This finding is consistent with data reported for both string and MIH1 (Russell et al., 1989; Kumagai and Dunphy, 1991).

Taken together, these results suggested that either the cdc25Hs protein possessed intrinsic phosphatase activity or alternatively that it activated a phosphatase that copurified with $\mathrm{p} 34^{\mathrm{cdc} 2} /$ cyclin complexes isolated both from Xenopus oocytes and from insect cells. cdc25Hs lacks any obvious homology to known protein phosphatases, although Moreno and Nurse (1991) recently noted homology between $S$. pombe cdc25 and VH1, a phosphatase encoded by vaccinia virus that is capable of hydrolyzing phosphoserine and phosphotyrosine (Guan et al., 1991). The cdc25Hs protein contains a motif (HCXAGXXR) within its $C$ terminus that is conserved in the active site of all-known tyrosine- 
specific protein phosphatases. Mutation of the cysteine residue within this motif ablates the phosphatase activity of VH1 (Guan et al., 1991). In an attempt to establish a biochemically pure assay system for determining whether cdc $25 \mathrm{Hs}$ protein was indeed a phosphatase, we tested the ability of PNPP to be hydrolyzed by recombinant cdc25Hs protein. As shown in Figure 6, PNPP was hydrolyzed at a rate of nearly $10 \%$ that of PTP1B, indicating that the activity associated with p $80^{\text {GST-cdc25 }}$ was a biochemically significant activity. In addition, in this assay we utilized affinity-purified bacterially derived cdc $25 \mathrm{Hs}$ protein and an artificial substrate (PNPP), thus ruling out the possibility that a phosphatase other than cdc25 itself was responsible for the activity. These results indicate that the phosphatase activity is intrinsic to the cdc25Hs protein and that it may directly dephosphorylate $\mathrm{p} 34^{\mathrm{cdc} 2}$.

\section{ACKNOWLEDGMENTS}

We thank Andrea Schievella and Ray Erikson for PTP1B, Brian Druker and Tom Roberts for the anti-phosphotyrosine antibody, and Paul Russell for pBSK1. In addition, we thank Lew Cantley for his insightful suggestions throughout the course of this study. This work was supported by ACS JFRA-290 to H.P.-W., training grant HL07053 to M.S.L. and S.O., NIH grants CA 34456 to D.J.D. and GM26743 to J.L.M., and an ACS postdoctoral fellowship (MA division) to L.L.P. H.P.-W. is a PEW Scholar in the Biomedical Sciences.

\section{REFERENCES}

Beach, D., Durkacz, B., and Nurse, P. (1982). Functional homologous cell cycle control genes in budding and fission yeast. Nature 300, 706709.

Blow, J., and Nurse, P. (1990). A cdc2-like protein is involved in the initiation of DNA replication in Xenopus egg extracts. Cell 62, 855862.

Booher, R., Alfa, E., Hyams, J., and Beach, D. (1989). The fission yeast cdc2/cdc13/suc1 protein kinase: regulation of catalytic activity and nuclear localization. Cell 58, 485-497.

Brizuela, L., Draetta, G., and Beach, D. (1987). p13 $3^{\text {suc1 }}$ acts in fission yeast cell division cycle as a component of the $\mathrm{p} 34^{\mathrm{cdc} 2}$ protein kinase. EMBO J. 6, 3507-3514.

Chernoff, J., Schievella, A.R., Jost, C.A., Erikson, R.L., and Neel, B.G. (1990). Cloning of a cDNA for a major human protein-tyrosine-phosphatase. Proc. Natl. Acad. Sci. USA 87, 2735-2739.

Draetta, G., and Beach, D. (1988). Activation of cdc2 protein kinase during mitosis in human cells: cell cycle-dependent phosphorylation and subunit rearrangement. Cell 54, 17-26.

Draetta, G., Luca, F., Westendorf, J., Brizuela, L., Ruderman, J., and Beach, D. (1989). cdc2 protein kinase is complexed with both cyclin A and B: evidence for proteolytic inactivation of MPF. Cell 56, 829838.

Draetta, G., Piwnica-Worms, H., Morrison, D., Druker, B., Roberts, T., and Beach, D. (1988). Human cdc2 protein kinase is a major cellcycle regulated tyrosine kinase substrate. Nature 336, 738-744.

Dunphy, W.G., Brizuela, L., Beach, D., and Newport, J. (1988). The Xenopus cdc2 protein is a component of MPF, a cytoplasmic regulator of mitosis. Cell 54, 423-431.
Dunphy, W., and Newport, J. (1989). Fission yeast p13 blocks mitotic activation and tyrosine dephosphorylation of the Xenopus cdc2 protein kinase. Cell 58, 181-191.

Edgar, B.A., and O'Farrell, P.H. (1989). Genetic control of cell division patterns in the Drosophila embryo. Cell 57, 177-187.

Furukawa, Y., Piwnica-Worms, H., Ernst, T.J., Kanakura, Y., and Griffin, J.D. (1990). cdc2 gene expression at the G1 to $S$ transition in human T lymphocytes. Science $250,805-808$.

Gautier, J., Matsukawa, T., Nurse, P., and Maller, J. (1989). Dephosphorylation and activation of Xenopus $\mathrm{p} 34^{\text {cdc2 }}$ protein kinase during the cell cycle. Nature 339, 626-629.

Gautier, J., Minshull, J., Lohka, M., Glotzer, M., Hunt, T., and Maller, J.L. (1990). Cyclin is a component of maturation-promoting factor from Xenopus. Cell 60, 487-494.

Gautier, J., Norbury, C., Lohka, M., Nurse, P., and Maller, J. (1988). Purified maturation-promoting factor contains the product of a Xenopus homolog of the fission yeast cell cycle control gene $\mathrm{cdc}^{+}$. Cell 54, 433-439.

Gould, K.L., Moreno, S., Tonks, N., and Nurse, P. (1990). Complementation of the mitotic activator, $\mathrm{p} 80^{\mathrm{cdc} 25}$, by a human protein-tyrosine phosphatase. Science 250, 1573-1576.

Gould, K., and Nurse, P. (1989). Tyrosine phosphorylation of the fission yeast $\mathrm{cdc}^{+}$protein kinase regulates entry into mitosis. Nature $342,39-44$.

Guan, K., Broyles, S., and Dixon, J.E. (1991). A Tyr/Ser protein phosphatase encoded by vaccinia virus. Nature 350, 359-362.

Jimenez, J., Alphey, L., Nurse, P., and Glover, D.M. (1990). Complementation of fission yeast cdc2ts and cdc25ts mutants identifies two cell cycle genes from Drosophilia: a cdc2 homolog and string. EMBO J. 9, 3565-3571.

Kaelin, W.G., Pallas, D.C., Decaprio, J.A., Kaye, F., and Livingston, D.M. (1991). Identification of cellular proteins that can interact specifically with the T/E1A-binding region of the retinoblastoma gene product. Cell 64, 521-532.

Krek, W., and Nigg, E.A. (1991). Differential phosphorylation of vertebrate $\mathrm{p} 34^{\text {cdc2 }}$ kinase at the G1/S and G2/M transitions of the cell cycle: identification of major phosphorylation sites. EMBO J. 10, 305316.

Kumagai, A., and Dunphy, W.G. (1991). The cdc25 protein controls tyrosine dephosphorylation of the cdc2 protein in a cell-free system. Cell 64, 903-914.

Labbe, J.C., Lee, M.G., Nurse, P., Picard, A., and Doree, M. (1988). Activation at $\mathrm{M}$-phase of a protein kinase encoded by a starfish homologue of the cell cycle control gene cdc2. Nature 335, 251-254.

Lee, M., and Nurse, P. (1987). Complementation used to clone a human homolog of the fission yeast cell cycle control gene cdc2. Nature $327,31-35$.

Lewin, B. (1990). Driving the cell cycle: $M$ phase kinase, its partners and substrates. Cell $61,743-752$.

Lohka, M.J., Hayes, M.K., and Maller, J.L. (1988). Purification of maturation-promoting factor, an intracellular regulator of early mitotic events. Proc. Natl. Acad. Sci. USA 85, 3009-3013.

Lundgren, K., Walworth, N., Booher, R., Dembski, M., Kirschner, M., and Beach, D. (1991). mik1 and wee1 cooperate in the inhibitory tyrosine phosphorylation of cdc2. Cell 64, 1111-1122.

Meijer, L., Azzi, L., and Wang, J.Y.J. (1991). Cyclin B targets p34 ${ }^{\text {cdc2 }}$ for tyrosine phosphorylation. EMBO J. 10, 1545-1554.

Minshull, J., Blow, J.J., and Hunt, T. (1989). Translation of cyclin mRNA is necessary for extracts of activated Xenopus eggs to enter mitosis. Cell 56, 947-956. 
Minshull, J., Golsteyn, R., Hill, C.S., and Hunt, T. (1990). The A- and B-type cyclin associated cdc2 kinases in Xenopus turn on and off at different times in the cell cycle. EMBO J. 9, 2865-2875.

Moreno, S., Hayles, J., and Nurse, P. (1989). Regulation of p34 ${ }^{\text {cdc2 }}$ protein kinase during mitosis. Cell 58, 361-372.

Moreno, S., and Nurse, P. (1991). Clues to action of cdc25 protein. Science 351, 194.

Morla, A., Draetta, G., Beach, D., and Wang, J. (1989). Reversible tyrosine phosphorylation of cdc2: dephosphorylation accompanies activation during entry into mitosis. Cell 58, 193-203.

Murray, A.W., and Kirschner, M.W. (1989). Cyclin synthesis drives the early embryonic cell cycle. Nature 339, 273-280.

Murray, A.W., Solomon, M.J., and Kirschner, M.W. (1989). The role of cyclin synthesis and degradation in the control of maturation promoting factor activity. Nature 339, 280-286.

Nurse, P. (1990). Universal control mechanism regulating onset of M-phase. Nature 344, 503-507.

Nurse, P., and Bissett, Y. (1981). Gene required in G1 for commitment to cell cycle and in $\mathrm{G} 2$ for control of mitosis in fission yeast. Nature $292,558-560$.

Parker, L., Atherton-Fessler, S., Lee, M.S., Ogg, S., Falk, J.L., Swenson, K.I., and Piwnica-Worms, H. (1991). Cyclin promotes the tyrosine phosphorylation of $\mathrm{p} 34^{\text {cdc2 }}$ in a wee $1^{+}$dependent manner. EMBO J. 10, 1255-1263.

Pines, J., and Hunter, T. (1989). Isolation of a human cyclin cDNA: evidence for cyclin mRNA and protein regulation in the cell cycle and for interaction with $\mathrm{p}^{34^{\mathrm{cdc}}}$. Cell 58, 833-846.

Pines, J., and Hunter, T. (1990). Human cyclin A is adenovirus E1Aassociated protein $\mathrm{p} 60$ and behaves differently from cyclin B. Nature $346,760-763$
Reed, S. (1980). The selection of S. cerevisiae mutants defective in the START event of cell division. Genetics 95, 561-577.

Roy, L.M., Swenson, K.I., Walker, D.H., Gabrielli, B.G., Li, R.S. Piwnica-Worms, H., and Maller, J.L. (1991). Activation of $\mathrm{p} 34^{\text {dc2 }} \mathrm{ki}$ nase by cyclin A. J. Cell Biol. 113, 507-514.

Russell, P., Moreno, S., and Reed, S. (1989). Conservation of mitotic controls in fission and budding yeasts. Cell 57, 295-303.

Russell, P., and Nurse, P. (1986). cdc $25^{+}$functions as an inducer in the mitotic control of fission yeast. Cell 45, 145-153.

Russell, P., and Nurse, P. (1987). Negative regulation of mitosis by wee $^{+}$, a gene encoding a protein kinase homolog. Cell 45, 559-567.

Sadhu, K., Reed, S.I., Richardson, H., and Russell, P. (1990). Human homolog of fission yeast cdc25 mitotic inducer is predominantly expressed in G2. Proc. Natl. Acad. Sci. USA 87, 5139-5143.

Simanis, V., and Nurse, P. (1986). The cell cycle control gene cdc2+ of fission yeast encodes a protein kinase potentially regulated by phosphorylation. Cell 45, 261-268.

Solomon, M.J., Glotzer, M., Lee, T.H., Philippe, M., and Kirschner, M.W. (1990). Cyclin activation of p34 ${ }^{\text {cdc2 }}$. Cell 63, 1013-1024.

Strausfeld, U., Labbe, J.C., Fesquet, D., Cavadore, J.C., Picard, A., Sadhu, K., Russell, P., and Doree, M. (1991). Dephosphorylation and activation of a p34 ${ }^{\text {cdc2 }} /$ cyclin B complex in vitro by human CDC25 protein. Nature 351, 242-245.

Swenson, K., Farrell, K., and Ruderman, J. (1986). The clam embryo protein cyclin $A$ induces entry into $M$ phase and the resumption of meiosis in Xenopus oocytes. Cell 47, 861-870.

Westendorf, J., Swenson, K., and Ruderman, J. (1989). The role of cyclin B in meiosis 1. J. Cell Biol. 108, 1431-1443. 